\title{
Main Complications during Pregnancy and Recommendations for Adequate Antenatal Care in Sickle Cell Disease: A Literature Review
}

\section{Principais complicações durante a gestação $e$ recomendações para o cuidado antenatal na doença falciforme: Revisão da literatura}

\author{
Camilla Olivares Figueira ${ }^{10}$ Fernanda Garanhani Surita ${ }^{10} \quad$ Kleber Fertrin $^{2(1)}$

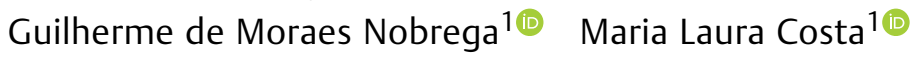

\footnotetext{
${ }^{1}$ Department of Obstetrics and Gynecology, Universidade Estadual de Campinas, Campinas, SP, Brazil Washington, Seattle, Washington, United States
} \\ 2 Division of Hematology, Department of Medicine, University of \\ Address for correspondence Maria Laura Costa, Rua Alexander \\ Fleming, 101, 13084-881, Campinas, SP, Brazil \\ (e-mail: mlaura@unicamp.br).
}

Rev Bras Ginecol Obstet 2022;44(6):593-601.

\begin{abstract}
Keywords

- sickle cell disease

- maternal morbidity

- maternal mortality

- pregnancy
\end{abstract}

\section{Resumo}

Sickle cell disease (SCD) is the most common monogenic disease worldwide, with a variable prevalence in each continent. A single nucleotide substitution leads to an amino-acid change in the $\beta$-globin chain, altering the normal structure ofhemoglobin, which is then called hemoglobin $S$ inherited in homozygosity (HbSS) or double heterozygosity ( $\mathrm{HbSC}, \mathrm{HbS} \beta$ ), and leads to chronic hemolysis, vaso-occlusion, inflammation, and endothelium activation. Pregnant women with SCD are at a higher risk of developing maternal and perinatal complications. We performed a narrative review of the literature considering SCD and pregnancy, the main clinical and obstetrical complications, the specific antenatal care, and the follow-up for maternal and fetal surveillance. Pregnant women with SCD are at a higher risk of developing clinical and obstetric complications such as pain episodes, pulmonary complications, infections, thromboembolic events, preeclampsia, and maternal death. Their newborns are also at an increased risk of developing neonatal complications: fetal growth restriction, preterm birth, stillbirth. Severe complications can occur in patients of any genotype. We concluded that SCD is a high-risk condition that increases maternal and perinatal morbidity and mortality. A multidisciplinary approach during pregnancy and the postpartum period is key to adequately diagnose and treat complications.

Doença falciforme (DF) é a condição genética mais comum no mundo, com uma prevalência variável nos continentes. A substituição de um nucleotídeo muda um aminoácido na cadeia da $\beta$ globina, e altera a estrutura normal da hemoglobina, que é received

August 3, 2021

accepted

November 3, 2021

published online

February 9, 2022
DOI https://doi.org/ 10.1055/s-0042-1742314. ISSN 0100-7203.
(C) 2022. Federação Brasileira de Ginecologia e Obstetrícia. All rights reserved.

This is an open access article published by Thieme under the terms of the Creative Commons Attribution License, permitting unrestricted use, distribution, and reproduction so long as the original work is properly cited. (https://creativecommons.org/licenses/by/4.0/)

Thieme Revinter Publicações Ltda., Rua do Matoso 170, Rio de Janeiro, RJ, CEP 20270-135, Brazil 


\begin{abstract}
então chamada de hemoglobina $\mathrm{S}$, e pode ser herdada em homozigose (HbSS) ou heterozigose (HbSC, HbSß), e leva a hemólise crônica, vaso-oclusão, inflamação, e ativação endotelial. Realizou-se uma revisão narrativa da literatura considerando doença falciforme e gestação, as complicações clínicas e obstétricas, o cuidado antenatal específico, e o seguimento para monitoramento materno e fetal. Gestantes com DF têm maior risco de desenvolver complicações clínicas e obstétricas, como crises dolorosas, complicações pulmonares, infecções, eventos tromboembólicos, préeclâmpsia, e morte materna. E seus recém-nascidos correm maior risco de desenvovler complicações neonatais: restrição de crescimento fetal, prematuridade e óbito fetal/ neonatal. Complicações graves podem ocorrer em qualquer genótipo da doença. Concluiu-se que DF é uma condição de alto risco que aumenta a morbimortalidade materna e perinatal. Um seguimento com abordagem multidisciplinar na gestação e puerpério é fundamental para o diagnóstico e o tratamento das complicações.
\end{abstract}

\section{Introduction}

Sickle cell disease (SCD) is the most common monogenic recessive inherited disease worldwide, and it was first described more than a century ago. ${ }^{1}$ Approximately 300 thousand children are born with the disease every year, ${ }^{2-4}$ and the prevalence of the mutated gene varies in each continent. In the Americas, the prevalence is of about 0.49 for every one thousand live births, 0.07 in Europe, 0.68 in South and Southeast Asia, and 10.68 in Africa. ${ }^{5}$ In Brazil, there are 2 million people carrying the sickle-cell gene mutation, and about 25 thousand to 50 thousand people with the homozygous form of the disease. ${ }^{6}$ The incidence in Brazil varies according to the state, from 1:650 live births in Bahia to 1:13,500 live births in Rio Grande do Sul. ${ }^{7}$

A single nucleotide substitution leading to a switch in a glutamic acid residue to a valine one in the $\beta$ globin chain turns normal hemoglobin into a structurally-abnormal one, called hemoglobin S (HbS), which causes SCD and is associated to endothelium activation and chronic inflammation. Other genotypes include hemoglobinopathy SC (HbSC), when the mutated hemoglobin Sis associated with hemoglobin C, and sickle beta thalassemia, when hemoglobin $S$ is associated with thalassemia mutations in the $\beta$ chain $(\mathrm{HbS} \beta)^{1,2,8,9}$ Those heterozygous forms may have better outcomes, ${ }^{10,11}$ although they are also associated with higher morbidity and mortality, especially during pregnancy and the postpartum period.

Complications in pregnancy include higher frequency of hypertensive disorders, (including preeclampsia), thromboembolic events, fetal demise, fetal growth restriction (FGR), preterm birth, ${ }^{12}$ and a higher risk of maternal death. ${ }^{11,13}$ Also, sickle cell complications, such as pain episodes, acute chest syndrome, anemia, and infections ${ }^{14,15}$ are common in pregnant women, ${ }^{12}$ and responsible for recurrent hospitalizations and morbidity.

\section{Pathophysiology of Sickle Cell Disease}

The polymerization of deoxyhemoglobin $S$ upon exposure to low oxygen levels deforms the membrane of red blood cells, which become elongated in the typical sickled shape, more adherent to endothelial cells, and less flexible. ${ }^{8}$ The same changes can also occur in reticulocytes. ${ }^{16}$ Red blood cell sickling shortens the lifespan of hemoglobins by removing them from circulation either by the reticuloendothelial system or intravascular hemolysis. ${ }^{8}$ The release of free hemoglobin from within red blood cells, along with sickling and cell adhesion to endothelial cells, leads to endothelial activation, generates cytokines, and activates the coagulation cascade in a systemic inflammatory response. ${ }^{17} \mathrm{Neu}-$ trophils and platelets are also activated, ultimately culminating in sickle cell vaso-occlusion, ${ }^{8,16}$ a hallmark of the disease, which is responsible for acute complications as well as end organ damage due to ischemia and inflammation. ${ }^{8}$ In the past 30 years, major advances in research have resulted in a better understanding of the pathophysiology of SCD, and earlier interventions during childhood, including the use of penicillin, vaccinations, screening and prevention of stroke, for example, have improved the quality of life of patients and have extended the life expectancy of people with SCD, enabling women to reach childbearing age ${ }^{18-21}$ and pursue pregnancy. Sickle cell disease is a chronic inflammatory condition, and pregnancy in such women is considered a high-risk condition ${ }^{14,22-26}$ that requires close follow up in specialized medical services with a multidisciplinary approach.

\section{Clinical and Obstetric Complications in SCD}

Several studies ${ }^{1,14,15}$ have reported maternal complications of SCD, including vaso-occlusive crises (VOCs, the most frequent cause of morbidity and hospitalization), infections (especially in the urinary tract), thromboembolic events (including deep venous thrombosis and stroke), pulmonary complications (the main cause of mortality), chronic renal failure, cesarian section, and maternal death. Fetal complications include FGR, low birth weight (LBW), prematurity, fetal distress during labor, and increased perinatal mortality. ${ }^{10,14,15,22,27}$ However, there is a great deal of variation among published reports regarding the 
incidence of complications due to different study designs, country or world region of the studied cases, access to healthcare, and even the absence of statistical analysis to account for confounding variables. ${ }^{12}$ A meta-analysis published in $2015^{10}$ compared maternal and perinatal outcomes among women with and without SCD. The study analyzed 26,349 women with SCD and compared them in groups according to the genotype (1,276 women with HbSS and 279 women with HbSC); however, the majority of SCD cases had no known genotype (24,794). The study reported an almost 18-fold increase in maternal mortality among women with SCD compared with non-SCD women, and a more than 2-fold risk of developing preeclampsia. No additional risk of developing eclampsia was found, except among those women with the HbSS genotype (an almost 5fold risk). The authors ${ }^{10}$ also reported a small increase in the risk of undergoing cesarean section in all SCD groups, and a higher risk of having stillbirth in both studied genotypes. Neonatal death and premature birth were twofold higher in the HbSS group only, and small for gestational age babies were more prevalent among SCD women than among the control group. ${ }^{10}$ A 2010 study $^{27}$ on mortality in SCD and the use of hydroxyurea (the first drug approved to treat SCD by increasing fetal hemoglobin production) showed a reduction in SCD complications such as painful episodes, blood transfusion, and acute chest syndrome, increasing the chance of patient survival from $65 \%$ to $86 \%$ in the from $65 \%$ to $86 \%$ in the treated group. ${ }^{27}$ Although hydroxyurea is not approved for use in pregnancy, its use may be considered after pregnancy and breastfeeding in order to improve quality of life and reduce hospitalizations. Another study, ${ }^{28}$ published in 2018, which evaluated adverse outcomes among patients with different SCD genotypes (HbSS, HbSC, and HbS $\beta$ thalassemia), included 89 women and found that 52\% were hospitalized during pregnancy for clinical or obstetrical complications. The main reasons for hospitalization were VOC (41\%) and obstetric adverse events (22\%), and most of them occurred in HbSS patients. However, the authors ${ }^{28}$ did not find statistically significant differences among the SCD genotypes. Perinatal outcomes such as LBW, prematurity, preeclampsia, and stillbirth were more frequent in the HbSS and HbSC groups, with no significant difference among the SCD groups. Postpartum adverse outcomes (hemorrhage, infections, and thromboembolic events) were significantly more frequent among the $\mathrm{HbS} \beta$ thalassemia group (57\%) compared with the HbSS (18\%) and HbSC (13\%) groups. ${ }^{28}$ Another study, ${ }^{29}$ with 62 SCD pregnancies, compared the complications within the 3 genotypes (HbSS, HbSC, and HbS $\beta$ thalassemia). Urinary tract infection was the most common complication, with similar frequencies in the HbSS and HbSC groups (30\% and 33\% respectively). The second most prevalent complication was VOC, and it was more frequent among HbSC pregnancies (27\%). Preeclampsia occurred in $11 \%$ of cases of HbSS, in $40 \%$ of cases of $\mathrm{HbS} \beta$, and in $20 \%$ of $\mathrm{HbSC}$ pregnancies. Cesarian section was the delivery mode in $37 \%, 70 \%$, and $40 \%$ of the cases in the HbSS, HbSC, and $\mathrm{HbS} \beta$ thalassemia groups respectively.
The rates of prematurity were of $41 \%$ in the HbSS group, and of $23 \%$ in the HbSC group, with no reported cases among the $\mathrm{HbS} \beta$ thalassemia group. Stillbirth only occurred among the HbSS group (11\%), and no maternal deaths were reported in the study. ${ }^{29}$ In Nigeria, a study ${ }^{24}$ compared 50 HbSS women with normal controls, and the results showed a higher frequency of pregnancy-induced hypertension (28\% in the HbSS group and $6 \%$ the in control group) and $32 \%$ of VOC in the SCD group. The authors ${ }^{24}$ also found $16 \%$ of patients with FGR and no cases in the control group. Preterm delivery was also more frequent in the HbSS group ( $28 \%$ versus $10 \%$ ). Overall, complications were significantly higher in the HbSS group, occurring in $92 \%$ of the women (versus $38 \%$ in the controls). ${ }^{24}$ The high frequency of complications in SCD pregnancies corroborates the need for early diagnosis and surveillance to reduce morbidity and mortality. Maternal mortality ranges from $1 \%$ in a retrospective study conducted in the United States ${ }^{30}$ to $9.2 \%$ in a Nigerian study. ${ }^{31}$ That discrepancy may be due to differences in the quality of care, including early diagnosis and treatment of complications, as well as under-reporting of cases. Near miss is a condition in which women survive a severe complication during pregnancy, childbirth, or within 42 days of the postpartum period. In Latin America, it is estimated there are 34 cases of near miss to every one thousand live births, ${ }^{32}$ and 15 cases of near miss for each maternal death. ${ }^{33,34}$ About a third of SCD pregnant women face a near miss event during pregnancy or the puerperal cycle, especially due to acute chest syndrome, a severe form of VOC affecting the lungs, and the leading cause of death in adult SCD patients. ${ }^{27,35}$ Unsurprisingly, SCD increases the possibility that a woman will experience a near miss event during pregnancy and/or the postpartum period. Despite the acute maternal severity of a near miss condition, this event is also associated with LBW and very low birth weight newborns, newborn admission to intensive care, stillbirth, early neonatal death, and long maternal hospital stays. $^{32,36-38}$ Studies with SCD in pregnancy usually involve a small number of patients due to the relative rarity of the condition and the difficulties in the compilation of data. A summary of meta-analyses on SCD during pregnancy found in the PubMed, SciELO, and Embase databases is presented in -Table 1.

\section{Antenatal Care}

Since SCD is a chronic systemic condition, pregnancy should ideally be planned in order to minimize possible complications. One main concern is regarding the use of medications for SCD during pregnancy and lactation. Common medications used in SCD management that should be discontinued before and during pregnancy include angiotensin-converting enzyme (ACE) inhibitors, iron chelators, and hydroxyurea. The use of hydroxyurea is not recommended, and women are advised to avoid conception up to 6 months after their last dose of hydroxyurea due to animal studies showing teratogenicity, and a few case reports of fetal growth abnormality and preterm birth. For more recently-approved SCD-specific therapies, the antioxidant aminoacid L-glutamine is generally considered to 
Table 1 Systematic Reviews on Sickle Cell Disease during Pregnancy

\begin{tabular}{|c|c|c|c|c|}
\hline $\begin{array}{l}\text { Author (year, } \\
\text { country) }\end{array}$ & Study design & $\begin{array}{l}\text { Number of studies } \\
\text { and/or women }\end{array}$ & Outcomes & Conclusions \\
\hline $\begin{array}{l}\text { Oteng-Ntim et al. }{ }^{10} \\
\text { ( } 2015, \text { United } \\
\text { Kingdom) }\end{array}$ & Meta-analysis & 26,349 SCD women & $\begin{array}{l}\text { MM (RR: 18.51; 95\%Cl: } \\
\text { 8.63-39.72) } \\
\text { PE (RR: 2.06; 95\%Cl: } \\
\text { 1.49-2.85) } \\
\text { CS (RR: 1.27; 95\%Cl: } \\
\text { 1.18-1.36) } \\
\text { ND (RR: 2.68; 95\%Cl: } \\
\text { 1.49-4.82) }\end{array}$ & $\begin{array}{l}\text { Pregnant women with } \\
\text { SCD have high risks of } \\
\text { developing maternal } \\
\text { and perinatal adverse } \\
\text { outcomes; } \\
\text { risks are greatest for } \\
\text { those in low-income } \\
\text { countries and for } \\
\text { those with HbSS dis- } \\
\text { ease compared to } \\
\text { HbSC }\end{array}$ \\
\hline \multirow[t]{10}{*}{$\begin{array}{l}\text { Boafor et al. }{ }^{37} \\
\text { (2016, Ghana, Nigeria, } \\
\text { and United States) }\end{array}$} & Meta-analysis & - 9 studies & $\begin{array}{l}\text { MM (OR: 10.91; } 95 \% \\
\mathrm{Cl}: 1.83-65.11 \\
p=0.009)\end{array}$ & \multirow{10}{*}{$\begin{array}{l}\text { SCD increases the risk } \\
\text { of adverse maternal } \\
\text { and perinatal out- } \\
\text { comes in low- and } \\
\text { high-income countries }\end{array}$} \\
\hline & & - 12 studies & $\begin{array}{l}\text { PE (OR: } 2.05 ; 95 \% \mathrm{Cl}: \\
1.47-2.85 ; p<0.001)\end{array}$ & \\
\hline & & - 13 studies & $\begin{array}{l}\text { CS (OR: } 1.54 ; 95 \% \mathrm{Cl}: \\
1.27-1.87 ; p<0.001)\end{array}$ & \\
\hline & & - 6 studies & $\begin{array}{l}\text { ND (OR: } 2.71 ; 95 \% \mathrm{Cl} \text { : } \\
1.41-5.22 ; p<0.003)\end{array}$ & \\
\hline & & - 10 studies & $\begin{array}{l}\text { FGR (OR: 2.69; 95\%Cl: } \\
1.85-4.21 ; p<0.001)\end{array}$ & \\
\hline & & - 6 studies & $\begin{array}{l}\text { Perinatal mortality } \\
\text { (OR: 3.76; 95\%Cl: } \\
\text { 2.34-6.06; } p<0.001 \text { ) }\end{array}$ & \\
\hline & & - 11 studies & $\begin{array}{l}\text { Prematurity (OR: 2.14; } \\
\text { 95\%Cl: 1.56-2.95; } \\
p<0.001)\end{array}$ & \\
\hline & & - 9 studies & $\begin{array}{l}\text { LBW (OR: } 2.00 ; 95 \% \mathrm{Cl} \text { : } \\
1.42-2.83 ; p<0.001)\end{array}$ & \\
\hline & & - 10 studies & $\begin{array}{l}\text { Stillbirth (OR: 4.05; } \\
95 \% C l: 2.59-6.32 \\
p<0.001)\end{array}$ & \\
\hline & & - 6 studies & $\begin{array}{l}\text { Infection (OR: 2.48; } \\
95 \% C l: 1.23-5.01 \\
p=0.011)\end{array}$ & \\
\hline $\begin{array}{l}\text { Inparaj et al. }{ }^{38} \\
\text { (2020, United } \\
\text { Kingdom) }\end{array}$ & Meta-analysis & 3,964 Patients & $\begin{array}{l}\text { ACS/pneumonia } \\
\text { (event rate: } 6.46 \% ; \\
95 \% C l: 4.66-8.25 \text { ); } \\
\text { Pulmonary thrombo- } \\
\text { embolism (RR: } 7.74 \text {; } \\
95 \% C l: 4.65-12.89 \text { ) }\end{array}$ & $\begin{array}{l}\text { Strong association be- } \\
\text { tween SCD and ma- } \\
\text { ternal pulmonary } \\
\text { complications }\end{array}$ \\
\hline
\end{tabular}

Abbreviations: 95\%Cl, 95\% confidence interval; ACS, acute chest syndrome; CS, cesarian section; FGR, fetal growth restriction; LBW, low birth weight; MM, maternal mortality; ND, neonatal Death; OR, odds ratio; PE, preeclampsia; RR, risk ratio; SCD, sickle cell disease.

be safe, the antisickling agent voxelotor is safe through pregnancy but not recommended during lactation, and there are no data on the anti-adhesive monoclonal antibody crizanlizumab. Care for pregnancy in SCD patients must include specialized antenatal care, since complications can occur at early gestational ages. Pregnancy in SCD patients requires more frequent follow-up, including a multidisciplinary team ${ }^{22,26,39}$ with an obstetrician, with close fetal surveillance, hematological support, nutritional and psychological assessments, and an ultrasonographist experienced in materno-fetal medicine. It may be convenient that appointments with the obstetrician take place at least monthly in the first and second trimesters, and more frequently after that, with individual assessment. It is paramount to check the immunization status and update it when necessary, taking into consideration that SCD patients require broader coverage for encapsulated bacteria (such as Streptococcus pneumoniae, Haemophilus influenzae, and Neisseria). Laboratory checks must include hemoglobin level, hemolytic markers (reticulocyte count and lactate dehydrogenase $[\mathrm{LDH}]$ ), and screening for infections (especially urinary 
tract infection and asymptomatic bacteriuria), more frequently than for a low-risk pregnancy. Anemia during pregnancy is defined by the World Health Organization (WHO) as a hemoglobin level below $11 \mathrm{~g} / \mathrm{dL}^{40,41}$ at any trimester of gestation. Maternal anemia is a common condition even for women with normal hemoglobin, especially during the last trimester of pregnancy, when the levels of iron need to be increased. ${ }^{42}$ When anemia presents in the first and second trimesters, it may contribute to LBW, prematurity, and neonatal complications. ${ }^{42-44}$ Chronic anemia is a very common feature of SCD, and it impacts patients since the beginning of pregnancy. However, it is important to assess if there are additional contributors to maternal anemia, such as nutritional deficiencies. Anemia can negatively affect fetal development, resulting in a growth-restricted fetus. ${ }^{43-46}$ The hemoglobin level of these patients can be very low, and the need for blood transfusion is common. Therefore, many studies have evaluated the benefits of prophylactic blood transfusion during pregnancy. Transfusion of red blood cells aims to improve the oxygen-carrying capacity. It can be performed through simple transfusion, when the goal is to achieve a certain level of hemoglobin, or exchange transfusion (manual or automated erythrocytapheresis), ${ }^{47}$ when the aim is to decrease the levels of circulating $\mathrm{HbS}$. In acute complications that lead to severe anemia, simple transfusion is usually the choice. Those transfusions aim to increase hemoglobin, taking it to levels closer to baseline while avoiding hyperviscosity and heart failure. ${ }^{8}$ Red blood cell transfusions can also be chronically used for stroke prevention, and acutely to treat acute chest syndrome or multiorgan failure. ${ }^{8}$ Exchange transfusion has been used during pregnancy to reduce the occurrence of complications, but there is no definitive evidence to indicate it to all patients. If red blood cell exchange is indicated in pregnancy, reasonable targets would be a level of $\mathrm{HbS}$ lower than $40 \%$, with a level of hemoglobin of $10 \mathrm{~g} / \mathrm{dL}^{48}$ A meta-analysis published in $2015^{49}$ concluded that prophylactic transfusion was associated with lower maternal mortality, VOCs, pulmonary complications, perinatal and neonatal mortality, and premature delivery, but no improvement in preeclampsia and FGR. Other studies reinforce the findings of lower maternal mortality ${ }^{50}$ and VOCs ${ }^{50,51}$ with prophylactic transfusion. A 2007 Brazilian study $^{52}$ found better fetal outcomes with fewer cases of FGR and preterm deliveries. Nevertheless, there is no consensus regarding the ideal hemoglobin level during pregnancy or the best moment to start transfusions in pregnant SCD patients. Some authors ${ }^{50}$ recommend starting transfusions in the second trimester while others ${ }^{53,54}$ recommend an earlier start, in the first trimester. A more conservative approach is to transfuse pregnant patients who have severe anemia with $\mathrm{Hb}$ below $7 \mathrm{~g} / \mathrm{dL}$, or any level of anemia if signs of impaired fetal growth or fetal distress are observed. To make this decision, providers should also consider that the more transfusions, the greater the risk of alloimmunization, which is of about $16 \%$ to $20 \%$ in this population. ${ }^{26,50}$ Alloimmunization can lead to lifetime difficulty to find compatible blood and delayed hemolytic transfusion reactions, ${ }^{55}$ the latter sometimes manifesting with hyperhemolisis syndrome, a life-threatening situation in which hemoglobin levels drop to below pretransfusion levels.

\section{Placental Findings in SCD}

The placenta is an organ with an adapted surface for oxygen and nutrient exchange between the maternal and fetal circulations. ${ }^{56}$ Studies on $\mathrm{SCD}^{57,58}$ have shown placental abnormalities such as syncytial knots, villous necrosis, congestion, deposits of sickle hemoglobin, and intravillous fibrin. Increased expression of proinflammatory genes in the placenta have been documented, suggesting that the organ is exposed to a proinflammatory environment and hypoxia, ${ }^{46}$ and the imbalance in inflammatory substances could favor vaso-occlusive episodes and necrosis. ${ }^{48,57}$ Furthermore, abnormal placental size, location, and adhesion to the uterine wall have also been described in SCD pregnancies. The exact pathophysiology explaining how abnormalities in placental development can contribute to worse perinatal outcomes and complications in SCD is not yet fully understood. However, those abnormalities may increase the risk of uteroplacental insufficiency, leading to maternal and fetal adverse outcomes. ${ }^{46}$

\section{Fetal Surveillance and Risk of Fetal Growth Restriction}

Fetal growth restriction occurs when the fetus does not reach its biological growth potential and is usually associated to placental insufficiency. ${ }^{59}$ Those fetuses are at a higher risk of adverse outcomes in pregnancy, higher morbidity and mortality, and impaired neurological development, ${ }^{60,61}$ which makes recognition and appropriate follow-up of such cases essential. Statistical deviations from population-based reference growth curves define FGR. ${ }^{62}$ For fetal assessment, the ultrasound (US) scan is the preferred method to evaluate fetal wellbeing, as it can estimate fetal weight (which is especially important during the third trimester) and detect placental impairment with Doppler velocimetry; therefore, it should be part of the regular antenatal care. However, due to the heterogeneity among SCD patients, there is no specific recommended protocol for US follow up. We suggest performing US at least once during the first and the second trimesters, and then monthly until delivery. That seems like a reasonable approach if there is no major complication, and providers should consider shorter scan intervals if necessary. During the third trimester, closer follow-up with a two-week interval if there is early suspicion of fetal impairment is acceptable.

\section{Diagnosis and Treatment of Complications during Pregnancy}

The complications of SCD may have distinct presentations and should always be suspected based on patient's history and examination. The symptoms may mimic common pregnancy discomforts, delaying adequate healthcare. I most frequent complication is VOC, which is typically experienced as acute bone or joint pain that starts abruptly. Uncomplicated VOCs last for four to five days on average. The severity of the pain also varies widely, but severe pain often requires admission. The treatment of VOC is based on hydration, 
analgesia, and treatment of the precipitating factors. Common triggers for VOC include dehydration, sudden changes in temperature (including but not limited to cold exposure), infections (including urinary tract infection, pneumonia, acute osteomyelitis etc.), delayed transfusion reactions, thromboembolic events, the acute phase of avascular necrosis, and emotional distress, but many VOCs will not have an identifiable trigger. Controlled fluid management should be enough to reduce blood viscosity, but must not be overdone to avoid acute pulmonary edema. There is no scientific evidence to recommend a specific type of intravenous fluid, and providers can freely choose to use normal saline, sodium chloride $(\mathrm{NaCl})$ 0.45\%, Ringer lactate slution, and others. Analgesia must include non-opioid and/or opioid analgesics, depending on the intensity of the pain. ${ }^{63}$ The use of opioids during pregnancy increases the risk of neonatal complications, including withdrawal syndrome in the newborn, but should not be considered a contraindication to the use of opioids in this setting. Non-steroidal anti-inflammatory drugs are not recommended after 34 weeks gestation in order to avoid cardiac dysfunction with premature closure of the arterial canal. Transfusions should not be routinely indicated for VOCs, and should take into consideration if there is symptomatic anemia, and the potential risks associated with the procedure. Acute chest syndrome is a major complication characterized by a VOC with acute pain in the thoracic region associated with respiratory symptoms and fever, mostly associated with the finding of a new pulmonary opacity, and hypoxemia in severe cases. It is the main cause of death among adults with SCD. ${ }^{10}$ The treatment is symptomatic, with analgesia, fluid management, oxygen supplementation for oxygen saturation below $92 \%$, and ventilatory support if necessary. Simple transfusion may be indicated in patients with severe anemia $(\mathrm{Hb}<7 \mathrm{~g} / \mathrm{dL})$, and red blood cell exchange transfusion must always be considered for severe cases with hypoxemia. Acute chest syndrome is indistinguishable from pneumonia; therefore, the use of empiric broad-spectrum antibiotics is indicated, antivirals should be considered, and consultation with an infectious disease's specialist is encouraged to discuss options during pregnancy. The association of SCD and pregnancy increases the risk of deep-vein thrombosis and pulmonary embolism, so a low threshold to indicate lung computed tomography (CT) angiography is encouraged for patients with signs and symptoms of acute chest syndrome. While preeclampsia is known to be more frequent in SCD patients, the diagnosis of severe preeclampsia with hemolysis, elevated liver enzymes, and low platelet count (HELLP) syndrome may be challenging. Laboratory abnormalities caused by SCD delay the detection of hemolysis, since the levels of LDH and aspartate aminotransferase (AST) are increased by chronic hemolysis, and haptoglobin is already undetectable in SCD. In addition, HbSS patients may have a baseline elevated platelet count due to autosplenectomy, sometimes above 600 thousand, and HbSC or $\mathrm{HbS} \beta$ patients often have splenomegaly, leading to mild to moderate chronic thrombocytopenia in the 80 thousand to the 150 thousand range. Young patients may already have some degree of microalbuminuria prior to pregnancy, so early evaluation of the urinary sediment is encouraged as a baseline to help detect abnormal proteinuria later in pregnancy. Therefore, patients presenting with signs and symptoms suggestive of severe preeclampsia, such as headache and abdominal pain, should be carefully evaluated and monitored, and their laboratory evaluation must take into consideration their earlier results. We recommend keeping track of baseline urinalysis, $\mathrm{LDH}$, liver enzymes, and platelet counts and throughout pregnancy to help the diagnosis of preeclampsia and HELLP syndrome in SCD patients. Sickle cell disease complications such as sickle hepatopathy and hepatic sequestration should be considered differential diagnoses, since they may also lead to an increase in the levels of liver enzymes and worsen the anemia.

\section{Follow-up and Childbirth}

Vaginal delivery is possible, so SCD should not be regarded as an indication for cesarian section. Labor may occur spontaneously or after induction in SCD pregnant patients. During labor, it is important to be mindful of the patient's hydration status, provide appropriate analgesia, since those women are more prone to vaso-occlusive events during stressful situations, and ensure close fetal monitoring. Since SCD is a chronic systemic condition, pregnancy in SCD patients should ideally be planned in order to minimize possible complications. Women of reproductive age and those in the postpartum period must be counseled about contraceptive options. According to the WHO, contraceptive methods containing only progesterone (the pill, injectable contraceptives, implants, or intrauterine devices) are category 1 , meaning that the method can be used in any circumstance. Combined hormonal contraceptives and copper intrauterine devices are category 2 , meaning that the method can generally be considered, but should take into account the

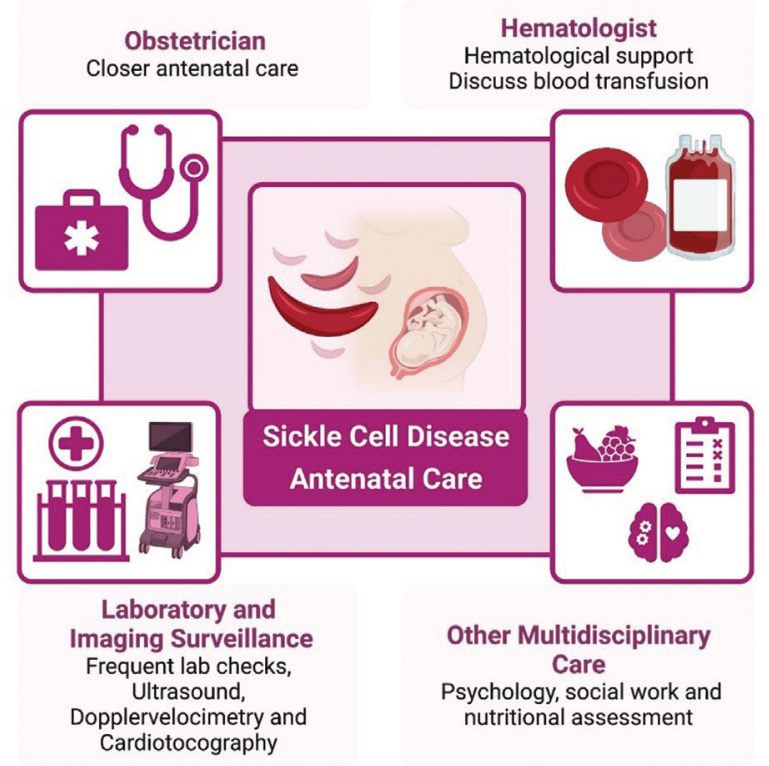

Fig. 1. Antenatal care of pregnant women with sickle cell disease (SCD). 


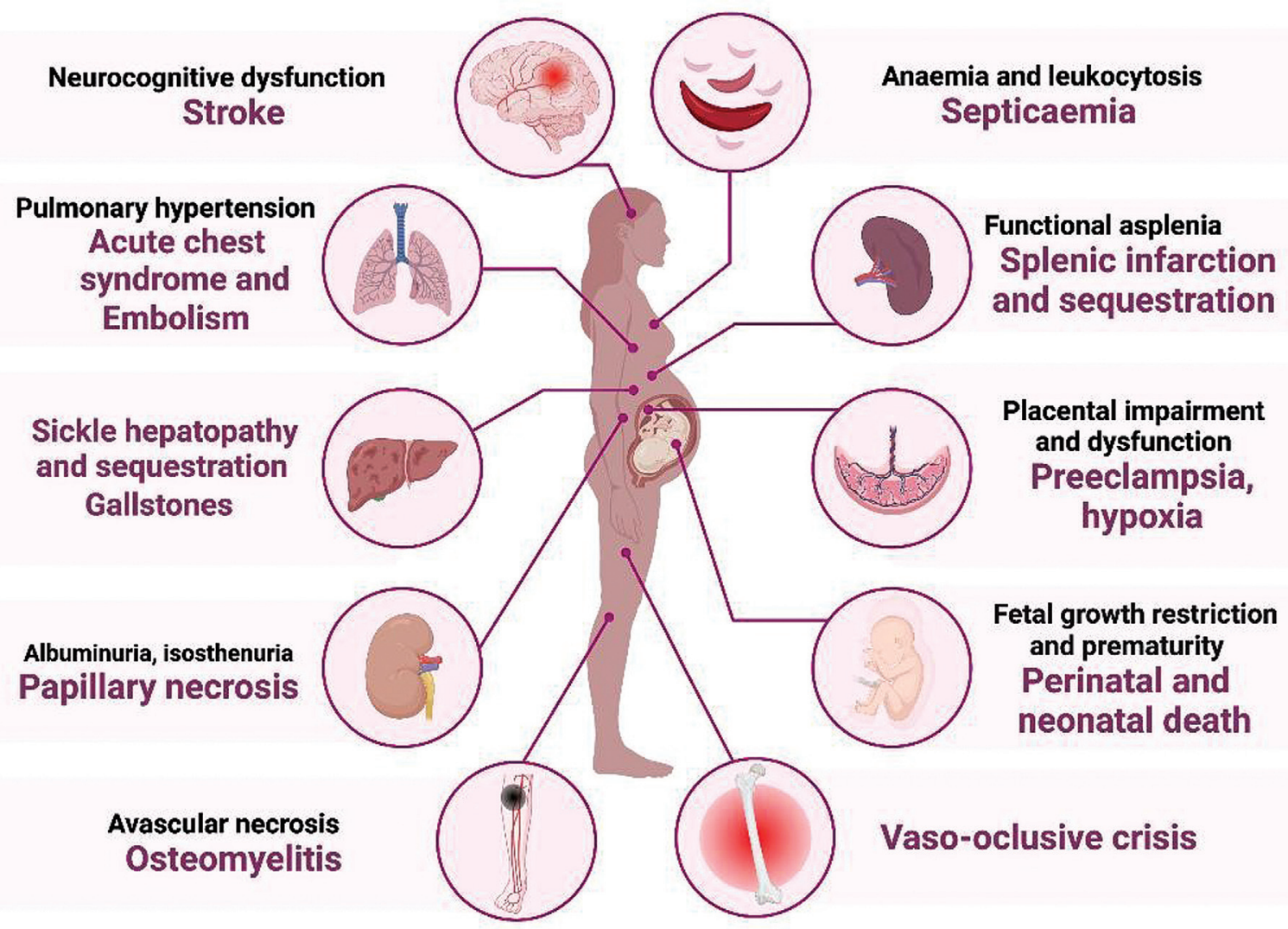

Fig. 2. Frequent complications in SCD.

individual risk of thromboembolic events, the history of menorrhagia, and patient preference. ${ }^{64}$ Psychological and nutricional support should happen together with antenatal and postpartum care, as these patients have higher rates of hospitalization and are more prone to develop depressive episodes ${ }^{65,66}$ and chronic nutritional deficiency. ${ }^{67}$ Sickle cell disease does not constitute a contraindication for breastfeeding, but the treatment with hydroxyurea is usually postponed until the patient is not breastfeeding. In addition, patients who were treated with blood transfusions during pregnancy should be evaluated for iron overload by their hematologist, particularly if chronically transfused. The indication for iron chelation therapy will depend on workup with serum ferritin, transferrin saturation, and liver magnetic resonance imaging. Low bone mineral density is a frequent complication of SCD, ${ }^{68}$ even in women of childbearing age, and may remain undiagnosed for many years. Pregnancy and breastfeeding contribute to deplete calcium from the bones, ${ }^{69}$ and we encourage providers to evaluate patients for osteopenia and osteoporosis with a dual-energy X-ray absorptiometry (DEXA) scan after they have finished breastfeeding, and verify vitamin D levels to provide supplementation if needed ( $\boldsymbol{-}$ Figures $\mathbf{1}$ and $\mathbf{2}$ ).

\section{Conclusion}

Sickle cell disease is a complex chronic disorder with potential life-threatening complications during pregnancy. The management of pregnant SCD patients requires a multidis- ciplinary approach to achieve favorable maternal and fetal outcomes, with accurate and timely diagnosis and treatment of its complications.

Conflict of Interests

The authors have no conflict of interests to declare.

Acknowledgements

The figures were created with the BioRender (BioRender, Toronto, ON, Canada) software.

\section{References}

1 Serjeant GR. The emerging understanding of sickle cell disease. $\mathrm{Br}$ J Haematol. 2001;112(01):3-18. Doi: 10.1046/j.1365-2141.2001. 02557.x

2 Howard J, Oteng-Ntim E. The obstetric management of sickle cell disease. Best Pract Res Clin Obstet Gynaecol. 2012;26(01):25-36. Doi: 10.1016/j.bpobgyn.2011.10.001

3 Piel FB, Patil AP, Howes RE, Nyangiri OA, Gething PW, Dewi M, et al. Global epidemiology of sickle haemoglobin in neonates: a contemporary geostatistical model-based map and population estimates. Lancet. 2013;381(9861):142-151. Doi: 10.1016/S0140-6736(12) 61229-X

4 Angastiniotis M, Modell B, Englezos P, Boulyjenkov V. Prevention and control of haemoglobinopathies. Bull World Health Organ. 1995;73(03):375-386

5 Asnani MR, Quimby KR, Bennett NR, Francis DK. Interventions for patients and caregivers to improve knowledge of sickle cell disease and recognition of its related complications. Cochrane Database Syst Rev. 2016;10(10):CD011175. Doi: 10.1002/ 14651858.CD011175.pub2 
6 Santo AH. Sickle cell disease related mortality in Brazil, 20002018. Hematol Transfus Cell Ther. 2020;•*::S2531-1379(20) 31299-2. Doi: 10.1016/j.htct.2020.09.154[ahead of print]

7 Silva-Pinto AC, Alencar de Queiroz MC, Antoniazzo Zamaro PJ, Arruda M, Pimentel Dos Santos H. The Neonatal Screening Program in Brazil, Focus on Sickle Cell Disease (SCD). Int J Neonatal Screen. 2019;5(01):11. Doi: 10.3390/ijns5010011

8 Ware RE, de Montalembert M, Tshilolo L, Abboud MR. Sickle cell disease. Lancet. 2017;390(10091):311-323. Doi: 10.1016/S01406736(17)30193-9

9 Weatherall DJ. ABC of clinical haematology. The hereditary anaemias. BMJ. 1997;314(7079):492-496. Doi: 10.1136/bmj.314.7079.492

10 Oteng-Ntim E, Meeks D, Seed PT, Webster L, Howard J, Doyle Pet al.Adverse maternal and perinatal outcomes in pregnant women with sickle cell disease: systematic review and metaanalysis. Blood. 2015;125(21):3316-3325 Doi: 10.1182/blood2014-11-607317

11 Oteng-Ntim E, Ayensah B, Knight M, Howard J. Pregnancy outcome in patients with sickle cell disease in the-K-a national cohort study comparing sickle cell anaemia (HbSS) with HbSC disease. Br J Haematol. 2015;169(01):129-137. Doi: 10.1111/ bjh. 13270

12 Smith-Whitley K. Complications in pregnant women with sickle cell disease. Hematology (Am Soc Hematol Educ Program). 2019; 2019(01):359-366. Doi: 10.1182/hematology.2019000039

13 Smith JA, Espeland M, Bellevue R, Bonds D, Brown AK, Koshy M. Pregnancy in sickle cell disease: experience of the Cooperative Study of Sickle Cell Disease. Obstet Gynecol. 1996;87(02): 199-204. Doi: 10.1016/0029-7844(95)00367-3

14 Wilson NO, Ceesay FK, Hibbert JM, Driss A, Obed SA, Adjei AA, et al. Pregnancy outcomes among patients with sickle cell disease at Korle-Bu Teaching Hospital, Accra, Ghana: retrospective cohort study. Am J Trop Med Hyg. 2012;86(06):936-942. Doi: 10.4269/ ajtmh.2012.11-0625

15 Boulet SL, Okoroh EM, Azonobi I, Grant A, Craig Hooper W. Sickle cell disease in pregnancy: maternal complications in a Medicaidenrolled population. Matern Child Health J. 2013;17(02): 200-207. Doi: 10.1007/s10995-012-1216-3

16 Kato GJ, Piel FB, Reid CD, Gaston MH, Ohene-Frempong K, Krishnamurti L, et al. Sickle cell disease. Nat Rev Dis Primers. 2018; 4:18010. Doi: $10.1038 /$ nrdp.2018.10

17 Ozdogu H, Sozer O, Boga C, Kozanoglu L, Maytalman E, Guzey M. Flow cytometric evaluation of circulating endothelial cells: a new protocol for identifying endothelial cells at several stages of differentiation. Am J Hematol. 2007;82(08):706-711. Doi: 10.1002/ ajh.20904

18 Wierenga KJ, Hambleton IR, Lewis NA. Survival estimates for patients with homozygous sickle-cell disease in Jamaica: a clinic-based population study. Lancet. 2001;357(9257):680-683. Doi: 10.1016/s0140-6736(00)04132-5

19 Telfer P, Coen P, Chakravorty S, Wilkey O, Evans J, Newell H, et al. Clinical outcomes in children with sickle cell disease living in England: a neonatal cohort in East London. Haematologica. 2007; 92(07):905-912. Doi: 10.3324/haematol.10937

20 Rogers DT, Molokie R. Sickle cell disease in pregnancy. Obstet Gynecol Clin North Am. 2010;37(02):223-237. Doi: 10.1016/j. ogc.2010.02.015

21 Hassell K. Pregnancy and sickle cell disease. Hematol Oncol Clin North Am.. 2005;19(05):903-16, vii-viii. Doi: 10.1016/j.hoc. 2005.07.003

22 Silva-Pinto AC, de Oliveira Domingues Ladeira S, Brunetta DM, De Santis GC, de Lucejáulo I, Covas DT. Sickle cell disease and pregnancy: analysis of 34 patients followed at the Regional Blood Center of Ribeirão Preto, Brazil. Rev Bras Hematol Hemoter. 2014; 36(05):329-333. Doi: 10.1016/j.bjhh.2014.07.002

23 Barfield WD, Barradas DT, Manning SE, Kotelchuck M, ShapiroMendoza CK. Sickle cell disease and pregnancy outcomes: women of African descent. Am J Prev Med. 2010;38(4, Suppl)S542-S549. Doi: $10.1016 /$ j.amepre.2009.12.020

24 Afolabi BB, Iwuala NC, Iwuala IC, Ogedengbe OK. Morbidity and mortality in sickle cell pregnancies in Lagos, Nigeria: a case control study. J Obstet Gynaecol. 2009;29(02):104-106. Doi: 10.1080/01443610802667112

25 Al-Farsi SH, Al-Riyami NM, Al-Khabori MK, Al-Hunaini MN. Maternal complications and the association with baseline variables in pregnant women with sickle cell disease. Hemoglobin. 2013;37(03):219-226. Doi: 10.3109/03630269.2013.780249

26 Andemariam B, Browning SL. Current management of sickle cell disease in pregnancy. Clin Lab Med. 2013;33(02):293-310. Doi: 10.1016/j.cll.2013.03.023

27 Nomura RM, Igai AM, Tosta K, da Fonseca GH, Gualandro SF, Zugaib M. [Maternal and perinatal outcomes in pregnancies complicated by sickle cell dijáses]. Rev Bras Ginecol Obstet. 2010;32(08):405-411

28 Silva FAC, Ferreira ALCG, Hazin-Costa MF, Dias MLG, Araújo AS, Souza AI. Adverse clinical and obstetric outcomes among pregnant women with different sickle cell disease genotypes. Int J Gynaecol Obstet. 2018;143(01):89-93. Doi: 10.1002/ijgo.12626

29 Elenga N, Adeline A, Balcaen J, Vaz T, Calvez M, Terraz A, et al. Pregnancy in sickle cell disease is a very high-risk situation: an observational study. Obstet Gynecol Int. 2016;2016:9069054. Doi: 10.1155/2016/9069054

30 Villers MS, Jamison MG, De Castro LM, James AH. Morbidity associated with sickle cell disease in pregnancy. Am J Obstet Gynecol. 2008;199(02):125.e1-125.e5. Doi: 10.1016/j.ajog.2008. 04.016

31 Dare FO, Makinde OO, Faasuba OB. The obstetric performance of sickle cell disease patients and homozygous hemoglobin $\mathrm{C}$ disease patients in Ile-Ife, Nigeria. Int J Gynaecol Obstet. 1992;37 (03):163-168. Doi: 10.1016/0020-7292(92)90376-t

32 Say L, Souza JP, Pattinson RCWHO working group on Maternal Mortality and Morbidity classifications. Matern-near miss-towards a standard tool for monitoring quality of maternal health care. Best Pract Res Clin Obstet Gynaecol. 2009;23(03):287-296. Doi: 10.1016/j.bpobgyn.2009.01.007

33 Penney G, Brace V. Near miss audit in obstetrics. Curr Opin Obstet Gynecol. 2007;19(02):145-150. Doi: 10.1097/GCO.0b013e $328014 a 860$

34 Lewis G. Beyond the numbers: reviewing maternal deaths and complications to make pregnancy safer. Br Med Bull. 2003; 67:27-37. Doi: 10.1093/bmb/ldg009

35 Resejáe Cardoso PS, Lopes Pessoa de Aguiar RA, Viana MB. Clinical complications in pregnant women with sickle cell disease: prospective study of factors predicting maternal death or near miss. Rev Bras Hematol Hemoter. 2014;36(04):256-263. Doi: 10.1016/ j.bjhh.2014.05.007

36 Souza JP, Cecatti JG, Parpinelli MA, Serruya SJ, Amaral E. Appropriate criteria for identification of near-miss maternal morbidity in tertiary care facilities: a cross sectional study. BMC Pregnancy Childbirth. 2007;7:20. Doi: 10.1186/1471-2393-7-20

37 Boafor TK, Olayemi E, Galadanci N, Hayfron-Benjamin C, DeiAdomakoh Y, Segbefia C, et al. Pregnancy outcomes in women with sickle-cell disease in low and high income countries: a systematic review and meta-analysis. BJOG. 2016;123(05): 691-698. Doi: 10.1111/1471-0528.13786

38 Inparaj S, Buckingham M, Oakley L, Seed PT, Lucas S, Oteng-Ntim E. Pulmonary complications for women with sickle cell disease in pregnancy: systematic review and meta-analysis. Thorax. 2020; 75(07):568-575. Doi: 10.1136/thoraxjnl-2019-213796

39 Rajab KE, Issa AA, Mohammed AM, Ajami AA. Sickle cell disease and pregnancy in Bahrain. Int J Gynaecol Obstet. 2006;93(02): 171-175. Doi: 10.1016/j.ijgo.2006.02.007

40 Kant S, Kaur R, Goel AD, Malhotra S, Haldar P, Kumar R. Anemia at the time of delivery and its association with pregnancy outcomes: A 
study from a secondary care hospital in Haryana, India. Indian J Public Health. 2018;62(04):315-318. Doi: 10.4103/ijph.IJPH_40_18

41 Suryanarayana R, Chandrappa M, Santhuram AN, Prathima S, Sheela SR. Prospective study on prevalence of anemia of pregnant women and its outcome: A community based study.J Family Med Prim Care. 2017;6(04):739-743. Doi: 10.4103/jfmpc.jfmpc_33_17

42 Scholl TO. Maternal iron status: relation to fetal growth, length of gestation, and iron endowment of the neonate. Nutr Rev. 2011;69 (Suppl 1):S23-S29. Doi: 10.1111/j.1753-4887.2011.00429.x

43 Haider BA, Olofin I, Wang M, Spiegelman D, Ezzati M, Fawzi WWNutrition Impact Model Study Group (anaemia) Anaemia, prenatal iron use, and risk of adverse pregnancy outcomes: systematic review and meta-analysis. BMJ. 2013;346:f3443. Doi: 10.1136/bmj.f3443

44 Sukrat B, Wilasrusmee C, Siribumrungwong B, McEvoy M, Okascharoen C, Attia J, et al. Hemoglobin concentration and pregnancy outcomes: a systematic review and meta-analysis. BioMed Res Int. 2013;2013:769057. Doi: 10.1155/2013/769057

45 Sun PM, Wilburn W, Raynor BD, Jamieson D. Sickle cell disease in pregnancy: twenty years of experience at Grady Memorial Hospital, Atlanta, Georgia. Am J Obstet Gynecol. 2001;184(06): 1127-1130. Doi: 10.1067/mob.2001.115477

46 Baptista LC, Costa ML, Ferreira R, Albuquerque DM, Lanaro C, Fertrin KY, et al. Abnormal expression of inflammatory genes in placentas of women with sickle cell anemia and sickle hemoglobin C disease. Ann Hematol. 2016;95(11):1859-1867. Doi: 10.1007/s00277-016-2780-1

47 Chou ST, Fasano RM. Management of patients with sickle cell disease using transfusion therapy: guidelines and complications. Hematol Oncol Clin North Am. 2016;30(03):591-608. Doi: 10.1016/j.hoc.2016.01.011

48 ACOG Committee on Obstetrics. ACOG Practice Bulletin No. 78: hemoglobinopathies in pregnancy. Obstet Gynecol. 2007;109 (01):229-237. Doi: 10.1097/00006250-200701000-00055

49 Malinowski AK, Shehata N, D'Souza R, Kuo KH, Ward R, Shah PS, et al. Prophylactic transfusion for pregnant women with sickle cell disease: a systematic review and meta-analysis. Blood. 2015;126 (21):2424-2435, quiz 2437. Doi: 10.1182/blood-2015-06-649319

50 Asma S, Kozanoglu I, Tarım E, Sarıturk C, Gereklioglu C, Akdeniz A, et al. Prophylactic red blood cell exchange may be beneficial in the management of sickle cell disease in pregnancy. Transfusion. 2015;55(01):36-44. Doi: 10.1111/trf.12780

51 Grossetti E, Carles G, El Guindi W, Seve B, Montoya Y, Creveuil C, et al. Selective prophylactic transfusion in sickle cell disease. Acta Obstet Gynecol Scand. 2009;88(10):1090-1094. Doi: 10.1080/ 00016340903134171

52 Gilli SC, De Paula EV, Biscaro FP, Marques JF, Costa FF, Saad ST. Third-trimester erythrocytapheresis in pregnant patients with sickle cell disease. Int J Gynaecol Obstet. 2007;96(01):8-11. Doi: 10.1016/j.ijgo.2006.09.017

53 Koshy M, Chisum D, Burd L, Orlina A, How H. Management of sickle cell anemia and pregnancy. J Clin Apher. 1991;6(04): 230-233. Doi: $10.1002 /$ jca.2920060412

54 Howard RJ, Tuck SM, Pearson TC. Pregnancy in sickle cell disease in the UK: results of a multicentre survey of the effect of prophylactic blood transfusion on maternal and fetal outcome. $\mathrm{Br} \mathrm{J}$ Obstet Gynaecol. 1995;102(12):947-951. Doi: 10.1111/j.1471-0528. 1995.tb10900.x
55 Dias Zanette AM, de Souza Gonçalves M, Vilasboas Schettini L, Magalhães Aguiar L, Santos Bahia RC, Vasconcelos Nogueira LA, et al. Alloimmunization and clinical profile of sickle cell disease patients from Salvador-Brazil. Ethn Dis. 2010;20(02): 136-141

56 Burton GJ, Fowden AL. The placenta: a multifaceted, transient organ. Philos Trans R Soc Lond B Biol Sci. 2015;370 (1663):20140066. Doi: 10.1098/rstb.2014.0066

57 Trampont P, Roudier M, Andrea AM, Nomal N, Mignot TM, Leborgne-Samuel Y, et al. The placental-umbilical unit in sickle cell disease pregnancy: a model for studying in vivo functional adjustments to hypoxia in humans. Hum Pathol. 2004;35(11): 1353-1359. Doi: 10.1016/j.humpath.2004.07.003

58 Thame M, Lewis J, Trotman H, Hambleton I, Serjeant G. The mechanisms of low birth weight in infants of mothers with homozygous sickle cell disease. Pediatrics. 2007;120(03):e686-e693. Doi: 10.1542/peds.2006-2768

59 Mifsud W, Sebire NJ. Placental pathology in early-onset and lateonset fetal growth restriction. Fetal Diagn Ther. 2014;36(02): 117-128. Doi: 10.1159/000359969

60 Lees C, Marlow N, Arabin B, Bilardo CM, Brezinka C, Derks JB, et al; TRUFFLE Group. Perinatal morbidity and mortality in early-onset fetal growth restriction: cohort outcomes of the trial of randomized umbilical and fetal flow in Europe (TRUFFLE). Ultrasound Obstet Gynecol. 2013;42(04):400-408. Doi: 10.1002/uog.13190

61 Pérez-Cruz M, Cruz-Lemini M, Fernánjáz MT, Parra JA, Bartrons J, Gómez-Roig MD, et al. Fetal cardiac function in late-onset intrauterine growth restriction vs small-for-gestational age, as defined by estimated fetal weight, cerebroplacental ratio and uterine artery Doppler. Ultrasound Obstet Gynecol. 2015;46(04): 465-471. Doi: 10.1002/uog.14930

62 American College of Obstetricians Gynecologists. ACOG Practice bulletin no. 134: fetal growth restriction. Obstet Gynecol. 2013; 121(05):1122-1133. Doi: 10.1097/01.AOG.0000429658.85846.f9

63 Ballas SK, Darbari DS. Review/overview of pain in sickle cell disease. Complement Ther Med. 2020;49:102327. Doi: 10.1016/ j.ctim.2020.102327

64 World Health Organization. Medical eligibility criteria for contraceptive use. 5th ed Geneva: WHO; 2015

65 Pecker LH, Darbari DS. Psychosocial and affective comorbidities in sickle cell disease. Neurosci Lett. 2019;705:1-6. Doi: 10.1016/j. neulet.2019.04.011

66 Adam SS, Flahiff CM, Kamble S, Telen MJ, Reed SD, De Castro LM. Depression, quality of life, and medical resource utilization in sickle cell disease. Blood Adv. 2017;1(23):1983-1992. Doi: 10.1182/bloodadvances.2017006940

67 Hyacinth HI, Gee BE, Hibbert JM. The role of nutrition in sickle cell disease. Nutr Metab Insights. 2010;3:57-67. Doi: 10.4137/NMI. S5048

68 Baldanzi G, Traina F, Marques Neto JF, Santos AO, Ramos CD, Saad ST. Low bone mass density is associated with hemolysis in Brazilian patients with sickle cell disease. Clinics (São Paulo). 2011;66(05): 801-805. Doi: 10.1590/s1807-59322011000500015

69 Ulrich U, Miller PB, Eyre DR, Chesnut CH III, Schlebusch H, Soules MR. Bone remodeling and bone mineral density during pregnancy. Arch Gynecol Obstet. 2003;268(04):309-316. Doi: 10.1007/ s00404-002-0410-8 